\title{
回腸導管の臨床的検討
}

\author{
九州大学医学部泌尿器科 神 崎 仁 徳
(主任 百瀬俊郎授)
}

\section{ILEAL CONDUIT URINARY DIVERSION}

\author{
Hitonori Kamizaki \\ Department of Urology, Faculty of Medicine, Kyushu University
}

(Director: Prof. S. Momose)

Fifty seven cases of ileal conduit urinary diversion were performed in Kyushu University during 13 years from 1963 to 1976 .

Wound infection was the most common complication followed by intestinal obstruction, upper urinary tract calculus, and urinary fistula. It seemed that malignant disease group had more early complications and benign disease group had more late complications.

Thirty per cent of upper urinary tracts in benign disease group deteriolated on intra-venous urogram, though 9.1 per cent in malignant disease group deteriolated $(\mathrm{p}<0.05)$.

One hundred and twenty four urines were obtained by the method of double lumen catheter for bacteriological examination. 50 per cent of urines included over $10^{5}$ bacteria per $\mathrm{ml}$. in benign disease group, though 14.3 per cent in malignant disease group $(p<0.05)$. Correlation was noted between pre- and post-operative urogram findings and urinary tract infections.

Five years survival rate of the urinary bladder cancer was 58 per cent. Radical cystectomy showed better result ( 82 per cent) than simple cystectomy ( 46 per cent).

\section{はじめに}

腸管を代用尿路として用いる方法は古くょり試みられ て来たが，遊離回腸片を導管として用いる，回腸導管法 は，1950年 Bricker により提唱されたものである ${ }^{1)}$. 最 初, Bricker は骨盤内悪性腫瘍摘除後の尿路変向法とし て，報告したが，そのすぐれた成績ゆえに，良性疾患に 対しても適応が広げられ，現在では最もすぐれた上部尿 路変向法之考光られつつある。

わが国に新いても，1960年代より本術式の報告がしだ いに增加しつつあるが23)，多数例の報告は少なく，末 た，本法による術後腎機能の推移や尿路感染の実態など についての報告例はいまだ多くない。

著者は, 今回, 九州大学泌尿器科に和いて1963年より 1976年末までに経験した，57症例について，1977年末ま での手術成績，合併症，術後腎機能，尿路感染などにつ いて検討を加えたので報告する。

\section{対象}

57例の原疾患，性別，年齢分布を Table 1 亿示す. 悪 性疾患 46 , 良性疾患11で, 前者は膀胱腫瘍が37例と大部
Table 1 原因疾患

\begin{tabular}{|c|c|c|c|c|}
\hline & 計 & 男 & 女 & 年齢（歳） \\
\hline 膀胱腫瘍 & 37 & 30 & 7 & $39 \sim 71$ \\
\hline 根治全摘 & (17) & $(16)$ & (1) & $(44 \sim 71)$ \\
\hline 単純全摘 & $(20)$ & (14) & (6) & $(39 \sim 69)$ \\
\hline 他悪性疾患 & 9 & 1 & 8 & $43 \sim 56$ \\
\hline 婦人科癌 & (8) & & (8) & $(43 \sim 56)$ \\
\hline 直腸癌 & (1) & (1) & (0) & $(44)$ \\
\hline 良性疾患 & 11 & 10 & 1 & $20 \sim 56$ \\
\hline 脊損膀桄 & (7) & (7) & $(0)$ & $(43 \sim 56)$ \\
\hline VUR & (1) & (1) & & $(58)$ \\
\hline 尿道外傷 & (1) & (1) & & (24) \\
\hline 尿管皮膚瘦より & (1) & & (1) & $(43)$ \\
\hline 神経因性膀胱 & (1) & (1) & & (20) \\
\hline
\end{tabular}

分を占めている.らち17例が根治的膀胱全摘例であり, 姑息的尿路変向例はない, 他の悪性疾患では, 子宮抒上 び胵癌 8 , 直腸癌 1 で, いずれも術後の尿路合併症を伴 つて扣り, その内訳は, 膀胱一胵一直腸瘦 4 , 膀羘一胵 
瘦 2 , 膀胼一直腸瘻 1 と尿瘻が大部分であり, 他に術後 神経因性膀脂による腎機能障害が 2 例であつた。な打こ れら症例の手術時期は原疾患手術より平均 4 年 7 月（最 長13年, 最短 6 月）経過していた。

良性疾患では，外傷性脊損に上る神経因性膀胱が 7 例 を占めている。

性別では男41，女16で，年㱓では最高71歳であつた。 良性疾患群11例の本法適応の主因をみると脊損 7 例で は，腎機能障害が 5 ，尿道瘦が 2 であった，受傷より尿 路変向までの期間は，平均 4 年 5 月（最長 7 年 8 月，最 短11月）であつた。他に小児麻痺による神経因性膀胱に 対し他院で行われた腎瘦術，婦人科良性疾患に対し他 院で行われた膀脱全摘 および両側尿管皮虐移植，重症 VUR，抢よび再建不能外傷性尿道狭窄がそれぞれ 1 例で あった。

これらの良性疾患群の術前の腎機能，尿路病態をみる と, 経過中発熱を認めたもの11例中 7 例，VUR を認め たもの 10 例中 8 例（1 例は尿管皮膚瘦にて検查不能）で あり, 内因性クレアチニンクリアランス值は 131 /day り $137 \mathrm{l} /$ day であつたが，ちち 4 例は $401 /$ day 以下で泃 つた。

\section{検索方法}

術後合併症，腎機能の推移，尿路感染，生存率などに ついて, 次のような方法で検索した。

1）術後合併症

入院，外来記録によった．便宜上，入院期間内発症を 早期合併症, 退院後発症を晚期合併症とした。

2）腎機能の推移

a ) IVP 所見の推移

6 力月間以上経過観察例について, 術前之可及的長期 経過後の所見を比較した．また術前 IVP 正常，異常群 別, 原疾患別にわけて比較検討した。

b ）血液生化学所見の推移

BUN, serum creatinine, Na, K, Cl, Ca kつき, 術 前, 術後 1 年, 2 年, 3 年, 4 年と経過を観察した。

3）尿中細菌検查

stoma におけりる污染を防ぐ目的で二重カテーテルを用 い，尿中細菌の検索を行つた。検査時期は術後 3 カ月以 上経た時とし，陽性とは生菌数 $10^{5} / \mathrm{ml}$ 以上を示し，ま た陽性例とは一度でも陽性に出た症例とした。

4）生存率と術後の生活状態

1977年末現在で検討した。膀朕腫瘍以外の死亡例は, 子宮癌術後症例 1 例であつたので主に膀胱腫瘍の生存率

\section{を検討した。}

根治膀胱全摘群，単純膀椫全摘群， high stage 例, low stage 例，それぞれについて実測生存率を算出し た. 膀胱腫瘍の stage 分類は $\mathrm{WHO}$ 分類 ${ }^{4}$ を用い, $\mathrm{P}_{2}$ 以下を low stage, $\mathrm{P}_{3}$ 以上を high stage とした.

な敃患者の生死については，病院受診記録および戸籍 により確認した。膀脱腫揚死亡例15例中 5 例は自宅死亡 であったが，病院記録掞よび死亡診断書確認の結果， 全例とも死因は癌死であった。また術後合併症（尿管填 死）のため，やむをえず腎瘦術に変更して生存中である 1 例は，きりか它時点で予後追跡不明例とした。

術後の生活状態は，生存者41名に対し，アンケートに て調査した。

\section{結 果}

1. 術後合併症

Table 2 のごとく早期合併症では創部感染が最も多 く，次いで腸閉塞，尿瘦，腸管出血などを認め，晚期合 併症では，上部尿路結石の新生，増大が最も多く急性腎 盂腎炎，尿管一腸吻合部狭窄による水腎，腸閉塞，慢性 腎不全がこれに次いでいる。

Table 2 術後合併症及び処置

\begin{tabular}{|c|c|c|c|c|c|}
\hline & & 良性 & $\begin{array}{l}\text { 悪性 } \\
\text { 咨患 }\end{array}$ & 計 & 外科的処置 \\
\hline \multirow{9}{*}{$\begin{array}{l}\text { 早 } \\
\text { 期 } \\
\text { 畣 } \\
\text { 症 }\end{array}$} & 創部感染 & 0 & 9 & 9 & 創掻爬 7, 再維合 2 \\
\hline & 腸 閉 塞 & 2 & 5 & 7 & 開腹術 4 \\
\hline & 尿摟 & 0 & 4 & 4 & 再吻合術 1 , 腎摜術 1 \\
\hline & 腸管出血 & 1 & 1 & 2 & \\
\hline & 直腸損傷 & 0 & 1 & 1 & 人工肛門 1 \\
\hline & 短腸症候群 & 0 & 1 & 1 & \\
\hline & 急性腎不全 & 0 & 1 & 1 & \\
\hline & 急性腎需腎炎 & 0 & 1 & 1 & \\
\hline & & 3 & 23 & 26 & \\
\hline \multirow{10}{*}{$\begin{array}{l}\text { 晩 } \\
\text { 期 } \\
\text { 合 } \\
\text { 併 } \\
\text { 症 }\end{array}$} & 永路結石（新生） & 0 & 3 & 3 & 腎部分切除 1 \\
\hline & 尿路結石（増大） & 2 & 0 & 2 & \\
\hline & 急性腎孟腎炎 & 0 & 3 & 3 & \\
\hline & 水腎症 & 0 & 3 & 3 & \\
\hline & 腸 閉 塞 & 1 & 1 & 2 & 開腹術 2 \\
\hline & 慢性腎不全 & 2 & 0 & 2 & \\
\hline & 膀胱蓄膿 & 1 & 0 & 1 & \\
\hline & 導管出血 & 0 & 1 & 1 & \\
\hline & 腸壁ヘルニア & 1 & 0 & 1 & \\
\hline & & 7 & 11 & 18 & \\
\hline
\end{tabular}


早期合併症の発生頻度をみると, 悪性疾患群では46例 中, 20 例 $(43 \%)$ 飞計23回, 良性疾患では 11 例中 3 例 （27\%）飞計 3 回発生している. 晚期合併症は悪性疾患 10例 (22\%) 飞11回，良性疾患 5 例 (46\%) 飞7 回及ら れた。早期抒よび晚期合併症ともに認めなからた症例 は悪性疾患で 46 例中 20 例 (43\%), 良性疾患 11 例中 3 例 (27\%) であつた。

次に，合併症に対して行つた処置について簡単に記 す.

まず腸閉塞は早期合併症として7 回, 晚期合併症とし て 2 回, 計 9 回 8 人に認められたが, 早期合併症の内 3 回は, 保存的療法にて軽快せしめた。他の 6 回に対して は開腹術を施行し救命せしめた。これら腸閉塞の原因は 空置回腸および盲腸間への回腸嵌頓, 癒着が原因であっ た。

腸管出血 2 例はいずれも胃潰瘍の発症であり, ともに 内科的治療で治癒した。

尿瘦 4 例は, すべて尿管回腸吻合部に発生し, 内 2 例 は保存的療法にて治癒せしめたが 1 例は単腎者で, 再吻 合術，他の 1 例は，両尿管下端壊死の状態で，やむなく 両腎㾞に変更した。

術後急性腎不全 1 例は，腹膜透析により救命せしめ た。

晚期合併症としての急性腎孟腎炎 3 例中 1 例は, 吻合 部狭窄例であるが，他の 2 例は正常の IVP 像を有して いるものであつた。

まれな合併症として, 短腸症候群 1 例が認められ た. 本症例は子宮癌術後の膀胼一胵瘦で, 術後 10 年を 経過し，また当時放射線療法を受けていたものである。 回腸導管施行時, 高度癒着のため 約 $80 \mathrm{~cm}$ の回腸切除 を余儀なくされた結果発症したものであるが，現在 cholestyramin の投与により, 症状は軽快している.

上部尿路結石の新生 3 例执よび増大 2 例の術前 IVP 所見は, 新生 1 例を除きいずれも水腎であつた, 治療と しては1例に対してのみ腎部分切除術を施行し, 他は保 存的治療にて観察中である. 腎部分切除例の結石分析の 結果はりン酸 $\mathrm{Ca}$, 炎酸 $\mathrm{Ca}$ の混合結石であつた。

術後慢性腎不全 2 例を認めた。この原疾患は脊損膀胱 および小児麻痺による神経因性膀脱に対する腎瘦例であ つた. 両者とも術前に腎機能障害を認め, 内因性クレア チニンクリアランスはそれぞれに13 1/day, 40 l/day で, 術後も徐々に腎機能障害が進行し, 現在, 慢性血液透析 中である.
Table 3 IVP 所見の推移

\begin{tabular}{l|c|c|c|c|c}
\hline \multicolumn{1}{c|}{ 原疾患 } & & 正常/改善 & 不変 & 悪化 & 悪化率 \\
\hline 悪性䓡患 & 77 & 59 & 11 & 7 & $9.1 \%$ \\
\hline 良性疾患 & 20 & 4 & 10 & 6 & $\begin{array}{c}30.0 \% \\
(\mathrm{p}<0.05)\end{array}$ \\
\hline 術前 I VP 所見 & & & & & \\
\hline 正 常 & 60 & 54 & & 6 & $10.0 \%$ \\
\hline 異 常 & 37 & 9 & 21 & 7 & $18.9 \%$ \\
\hline
\end{tabular}

他に膀脱蓄膿，導管出血，腹壁ヘルニアそれぞれ 1 例 を認めたが，保存的療法にて軽快している。

2. 腎機能の推移

a) IVP 所見の推移

Table 3 K IVP 所見の推移を腎単位で示した。なお 6 力月以上追跡不能例 5 , 拈よび癌の進展による水腎例 2 例は除外した。

術前正常腎が悪化する率は $10.0 \%$ ，術前水腎がより悪 化する率は $18.9 \%$ で，全体としての悪化率は $13.4 \%$ であ つた.

原疾患別にみてみると，悪性疾患の 悪化率 $9.1 \%$ に比 し，良性疾患の方が $30.0 \%$ とり高かった $(\mathrm{p}<0.05)$. また特に術前異常群が悪化する例が，良性疾患にて33.3 \% と悪性疾患 $5.2 \%$ 飞比し高かつた $(\mathrm{p}<0.05)$.

悪化した 9 例 13 腎の原因をみてみると，尿管一腸吻 合部狭窄 4 例 5 腎, 腎機能障害の進行（腎盂腎炎） 3 例 6 腎，上部尿路結石，原因不明それぞれ 1 例 1 腎であつ た。な持吻合部狭窄例以外は逆行性導管造影にて逆流が 証明された。

b ）血液生化学所見の推移

術前後の BUN, serum creatinine, $\mathrm{K}, \mathrm{Cl}$ の推移を Table 4 に示した。な括 $\mathrm{Na}$ 打よび $\mathrm{Ca}$ は全例とも正常 範囲内であつた。

\section{3. 尿中細菌検査}

二重カテーテルによる尿中細菌培養の 結果は Table 5-a に示すごとくである.

57 症例中 42 例（悪性疾患31，良性疾患11）に対しのべ 124回の培養を行なつた。

悪性疾患に打ける陽性者は6/31であり，良性疾患に 抢ける陽性者8/11に比し有意に低かつた $(\mathbf{p}<0.01)$. ま た，培盖回数でみた場合も悪性疾患では $12 / 84 ，$ 良性疾 患20/40 と良性疾患に扔いてょり陽性率が高かつた（p< $0.05)$.

術前, 術後の IVP 所見と陽性率を対比してみると, 
Table 4 生化学所見の推移

BUN

\begin{tabular}{|c|c|c|c|c|c|}
\hline & 術前 & 1 年後 & 2 年後 & 3 年後 & 4 年後 \\
\hline 正 常 & 32 & 38 & 22 & 16 & 10 \\
\hline 異 常 & 13 & 7 & 10 & 5 & 6 \\
\hline $\begin{array}{l}\text { 異常率 } \\
\end{array}$ & 29 & 16 & 31 & 24 & 38 \\
\hline
\end{tabular}

$\mathrm{Cr}$.

\begin{tabular}{c|c|c|c|c|c}
\hline & 術前 & 1 年後 & 2 年後 & 3 年後 & 4 年後 \\
\hline 正 常 & 32 & 38 & 25 & 14 & 12 \\
\hline 異 常 & 13 & 7 & 7 & 7 & 4 \\
\hline $\begin{array}{c}\text { 異常率 } \\
(\%)\end{array}$ & 29 & 16 & 22 & 33 & 25 \\
\hline
\end{tabular}

$\mathrm{K}$

\begin{tabular}{c|c|c|c|c|c}
\hline & 術前 & 1 年後 & 2 年後 & 3 年後 & 4 年後 \\
\hline 正 & 44 & 42 & 30 & 19 & 14 \\
\hline 異 常 & 1 & 3 & 2 & 2 & 2 \\
\hline $\begin{array}{c}\text { 異常率 } \\
(\%)\end{array}$ & 2 & 7 & 6 & 10 & 13 \\
\hline
\end{tabular}

$\mathrm{Cl}$

\begin{tabular}{c|c|c|c|c|c}
\hline & 術前 & 1 年後 & 2 年後 & 3 年後 & 4 年後 \\
\hline 正 常 & 45 & 43 & 32 & 21 & 16 \\
\hline 異 常 & 0 & 2 & 0 & 0 & 0 \\
\hline $\begin{array}{c}\text { 異常率 } \\
\text { (\%) }\end{array}$ & 0 & 4 & 0 & 0 & 0 \\
\hline
\end{tabular}

Table 5-a 尿中細菌培養

\begin{tabular}{c|c|c}
\hline 原疾患 & 陽性率 & 陽性者率 \\
\hline \multirow{2}{*}{ 悪性疾患 } & 陽性培養数/のべ培養数 & 陽性例数/症例数 \\
\cline { 2 - 3 } & $12 / 84(14.3 \%)$ & $6 / 31(19.4 \%)$ \\
\hline 良性疾患 & $\begin{array}{c}20 / 40(50.0 \%) \\
(\mathrm{p}<0.05)\end{array}$ & $\begin{array}{c}8 / 11(72.7 \%) \\
(\mathrm{p}<0.01)\end{array}$ \\
\hline
\end{tabular}

Table 5-b 術前後 IVP 所見と尿中細菌培養

\begin{tabular}{c|c|c|c}
\hline \multicolumn{2}{c|}{ IVP 所見 } & 陽性率 & 陽性者率 \\
\hline \multirow{3}{*}{ 術前 } & 正常 & $6 / 66(9.1 \%)$ & $3 / 24(12.5 \%)$ \\
\cline { 2 - 4 } & 翼常 & $\begin{array}{c}26 / 58(44.8 \%) \\
(\mathrm{p}<0.01)\end{array}$ & $\begin{array}{c}11 / 18(61.1 \%) \\
(\mathrm{p}<0.01)\end{array}$ \\
\hline \multirow{3}{*}{ 術後 } & 正常 & $2 / 50(4.0 \%)$ & $2 / 20(10.0 \%)$ \\
\cline { 2 - 4 } & 異常 & $\begin{array}{c}30 / 74(40.5 \%) \\
(\mathrm{p}<0.01)\end{array}$ & $\begin{array}{c}12 / 22(54.5 \%) \\
(\mathrm{p}<0.01)\end{array}$ \\
\hline
\end{tabular}

Table 5-b のごとく，いずれも IVP 所見異常者に有意 に高く認められた $(\mathrm{p}>0.01)$.

また分離された細菌は，培養124回中32回38株であ り, Proteus mirabilius 10, Pseudomonas aerginosa 8 , E. coli 4 の順で認められた.
4. 生存率と術後の生活状態

手術死亡例は認めなかつた。

膀胱腫瘍症例以外では, 子宮癌症例に癌死亡 1 例を認 めたのみで，他は全例生存が確認された。

膀胱腫瘍群の実測生存率 ${ }^{5}$ をみてみると, 全体の 5 年 生存率は58.0\%である.さらに尿道全摘, リンパ節廓清 を含を根治膀脱全摘群と，これらを含まない単純全摘群 とに分けて比較すると，前者が $81.8 \%$ と後者が $45.6 \%$ に 比し高い.

また，膀胱腫瘍の 組織学的浸潤度別に見てみると， low stage では根治群 $90.5 \%$ ，単純全摘群 $84.6 \%$ であ $\eta$, high stage $\left(\mathrm{P}_{3}\right.$ 以上) では根治群 $66.7 \%$, 単純群 26.0 \%であり，根治群が単純群に比し高かつた（Fig. 1).

尿路变向法の最終目的は社会復帰にあるが自験例では 生存者 41 名中, 入院中の 4 名を除き何らかの形で社会復 帰している。しかしながら，自験例では老人が多いため ああるが，男子においては，無職になつているもの 9 , 元の職場に㷌ったもの 4 , 転職したもの11となつてお り，やはり社会の壁の厚さを感じさせる．また女子では そのほとんどが主婦であるため, 元の家事労働に復帰し ている.

生存者 41 人について, 術後の生活状態についてアンケ 一トした結果 24 例に結果が得られた。これによると，入 浴はほぼ半数の $55 \%$ が毎日しており，隔日が $22 \%$ となつ ている. 退院後旅行したかについては68\%がしたことが 西ると答学て持り，術後生活が变化したかどうかについ ては $60 \%$ のが大幅に変化したと答えているも，かなり 普通人の生活が送れていることを物語つている. 装具に ついての経済的負担もかなりあるようで50\%の人が月 3 万円以上の経費がかかり，健保の適応を強く望んでい る.

\section{かんがえ}

腸管を用いる代用膀胱法は，括約筋を有する蓄尿形式 之，有しない導管形式のものに二分される。蓄尿形式の 場合は失禁がなく採尿器が不要である代りに, 合併症, 特に高クロル性酸血症の発生が多く, 手術成績が不安定 であることがあげられる。一方，導管形式の場合は，採 尿器の装着が必須であるが, 合併症が少なく, 手術成績 が安定するとされている6).

導管形式の場合, 空腸, 回腸, 回盲部, 結腸などが, すでに利用され，その優劣について種々議論されてい る. $\mathrm{Clark}^{7)}$ は空腸導管を形成した結果, 電解質バラン スの崩壊を 21 例中 9 例に認めたと報告している . 結腸を 
Fig. 1 膀胱腫湯例の生存率
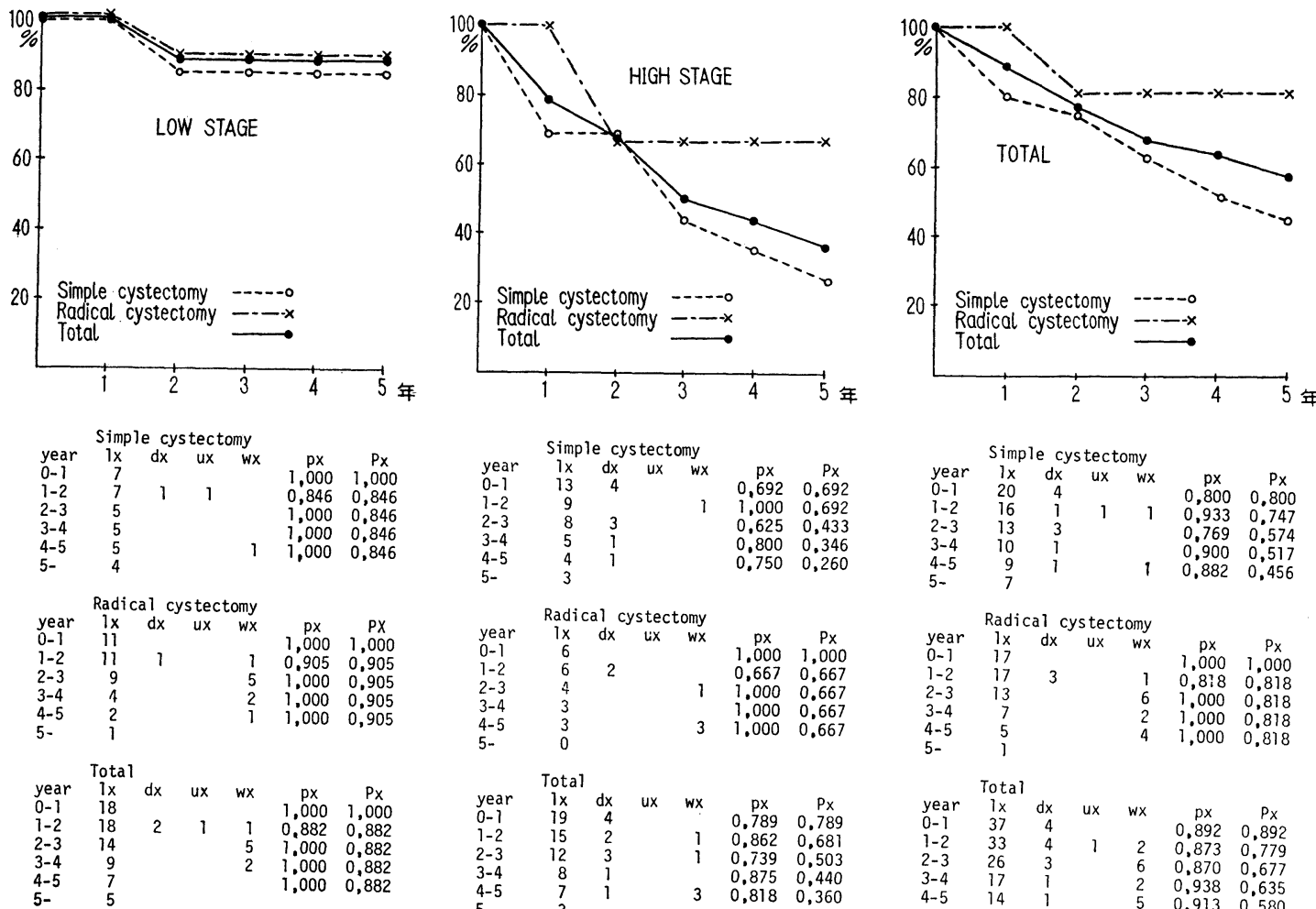

\begin{tabular}{|c|c|c|c|c|c|c|}
\hline & Tota & & & & & \\
\hline $\begin{array}{l}\text { year } \\
0-1\end{array}$ & $\begin{array}{l}1 x \\
19\end{array}$ & $\begin{array}{r}\mathrm{dx} \\
4\end{array}$ & $u x$ & $w x$ & $\begin{array}{c}\text { px } \\
780\end{array}$ & $\begin{array}{l}P x \\
0\end{array}$ \\
\hline $1-2$ & 15 & 2 & & 1 & $\begin{array}{l}0.189 \\
0.862\end{array}$ & $\begin{array}{l}0,789 \\
0.681\end{array}$ \\
\hline $2-3$ & 12 & 3 & & 1 & 0,739 & 0,503 \\
\hline $3-4$ & 8 & 1 & & & 0.875 & 0,440 \\
\hline $4-5$ & 7 & 1 & & 3 & 0,818 & 0,360 \\
\hline
\end{tabular}

\begin{tabular}{|c|c|c|c|c|c|c|}
\hline & Tot & & & & & \\
\hline $\begin{array}{l}\text { year } \\
0-1\end{array}$ & $\begin{array}{l}1 x \\
37\end{array}$ & $\begin{array}{r}d x \\
4\end{array}$ & $u x$ & & $\begin{array}{c}\text { px } \\
0.892\end{array}$ & $\begin{array}{l}P_{x} \\
0892\end{array}$ \\
\hline $1-2$ & 33 & 4 & 1 & 2 & 0,873 & $\begin{array}{l}0.892 \\
0.779\end{array}$ \\
\hline $2-3$ & 26 & 3 & & 6 & 0,870 & 0,677 \\
\hline $3-4$ & 17 & 1 & & 2 & 0,938 & 0,635 \\
\hline $4-5$ & 14 & 1 & & 5 & 0.913 & 0,580 \\
\hline
\end{tabular}

導管として用いる方法は Mogg の報告以来報告が増加 しつつある ${ }^{8)}$. Richie らは犬にて, 回腸導管と粘膜下ト ンネル形式の逆流防止式尿管腸吻合を行つた結腸導管の 腎の組織を比較した結果，回腸導管例では $83 \%$ に腎孟腎 炎の所見が得られたのに対し，結腸導管では $7 \%$ しかみ られなかつたと報告している9 。 Morales は46例の結腸 導管を報告， stoma に狭窄が生じにくい，電解質のみだ れが少ない，種々の部位に抽いても尿路变向が行ないや すいなどの利点を述べている ${ }^{10)}$ 。しかしながら，未だ報 告例数が充分でなく今後の 検討を要するものと思われ る。

回腸導管は当初 Bricker により, 骨盤内臓器全摘後の 尿路変向法として紹介されたがその後悪性腫瘍以外の良 性疾患，特に神経因性膀胼に対しても適応が広げられて 来た ${ }^{1)}$.

脊損膀胱に対しては，保存的療法を第一義とすべきこ とは言を待たないが，しかし，早期の適切な治療の機会 を失した場合，尿路変向を余儀なくされる症例があるこ ともまた事実である．尿路変向の適応としては，尿道周
囲膿瘍特よび瘦孔，くり返す上部尿路感染症腎不全を伴 ら進行性水腎症，女子尿失禁などがあげられている。こ れに対し，合併症，特に結石の発生が多いため，尿路変 向の適応を否定する意見もあるが，下部尿路障害として の尿失禁，尿道周囲膿瘍，尿道㾇牤よび上部尿路障害と しての腎機能低下などに対しての適応については，大方 の意見が一致していると考兄られる ${ }^{11)}$.

腸節を尿路に用いる場合，常に問題になる点として， 術前の腎機能障害がある。

本法の適応可能な腎機能の限界を正確に記した文献は 多くないが Creevy らは術前腎機能障害例に合併症が多 いことより，少なくとも腎不全には適応すべきではない と言い(12)，また Kaufman らは回腸節を尿路に用いる場 合は, serum creatinine 值が $3.0 \mathrm{mg} / \mathrm{dl}$ 以下である 必要 を述べ13，Smith らは腸管を用いる場合はクレアチニン クリアランス值にて $40 \mathrm{ml} / \mathrm{min}$. 以上ある必要があるとし ている14).

われわれは一応 serum creatinine $3.0 \mathrm{mg} / \mathrm{dl}$ を基準と 考えている. 
回腸導管術後の合併症については, 多くの報告がなさ れているが, Cordonnier らの初期の報告によれば, 191 例に拈いて 8 例の手術死を認めたほか, 早期合併症とし ては, 創離解 12 , 創感染 10 , 腸閉塞 9 , stoma 狭窄 6 , 腎不全 5 ，尿管腸吻合部閉塞 3 ，などを認めまた，晚期 合併症としては，急性腎孟腎炎16， stoma 狭窄15，水腎 症 12 , 結石 9 , 皮膚炎 8 , 腎不全 6 , 腸閉塞 5 などが あり，90人が合併症を一度も経験しなかつたという ${ }^{15)}$.

Engel らは215例飞打いて手術死 8 の他, stoma 狭窄 43 , 膀脱蓄膿 22 , 尿路結石 17 , 創感染 16 , 腸閉塞 13 , 尿管腸 吻合部狭窄 9 ，尿瘦 7 などを認め，208人中 98 人だけが， 5 年以上の経過の間に合併症がなかつたとしている。ま た，原因疾患別にみた場合，悪性疾患上り，良性疾患に 合併症が多いとし，合併症を招きやすい術前の状態とし て，尿路感染と放射線㙩法をあげている ${ }^{16)}$. Schmidt ら は178例について報告しているが，良性疾患では早期合

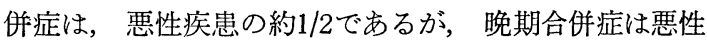
疾患の約培となり $92 \%$ に達するとしている ${ }^{17)}$.

著者の症例では手術死亡例は認められなかつたが，合 併症の頻度では，良性疾患では晚期合併症が多く，悪性 疾患では早期合併症が多いといら傾向を示していた。

ついで個々の合併症について $2 ， 3$ 考えてみる.

回腸導管後の腸閉塞の発生頻度は $2 \%$ よ $20 \%$ 之報告 されている ${ }^{18)}$. Manley は腸閉塞に対し48回開腹し, 内 41 回原因を確認した結果，全例とも盲腸が導管と壁側腹 膜の間に入りこんだためとし，予防法としては導管を盲 腸の後側に置くことが良いとした ${ }^{19)}$ 。一方 Bricker は彼 の初めての報告の中で lumber gutter を完全に閉じる必 要性を説いている1)。われわれは 8 人に対し 9 回経験 し, らち 6 回に開腹術を行なつている. 急性期に開腹し た 4 例についての術中所見は Manley らの所見と同じで 西つた，現在われわれは導管と回盲部を固定することに より，それ以後発症をみていない。

尿瘦については Hensle らは1,120例中21例に認め, 発 生部位としては尿管腸吻合部が最も多いとしている. 発 生は放射線治療をうけたものに多いとして拈り，診断は loopogram が最も有効であつたとしている。治療は 3 日 以内は保存的にして良いが，それ以上続けば外科手術が 必要と述べている20).

著者らは 4 例経験し，うち 2 例は保存的療法にて治癒 せしめたが，他の 2 例は外科治療が必要であつた。

過大な小腸切除は消化吸収不全を来たすことが知られ て打りわれれれも一例を経験した ${ }^{2122)}$. 終末回腸の主
たる作用は胆汁酸および Vitamin $B_{12}$ の吸収にあたると いわれており，広範に小腸切除を余儀なくされる症例に 括いては，他の腸節の利用も検討されるべき問題である $5^{23) 24)}$.

回腸導管術後に尿路結石の発生頻度が増すことはよく 知られている.Dretler は尿路変向後，結石を新たに発 症した36例について分析し，尿管拡張，腎機能低下，尿 素分解細菌による感染，導管内残尿が関連あるとしてい $3^{25)}$.

われわれは結石新生 3 例，増大 2 例を認めたが，これ らの症例の術前 IVP は 4 例まで水腎であり，また術後 全例飞感染を認め, Dretler の症例と同じ傾向を示して Wた.

回腸導管術後の腎機能の評価法については種々議論の あるところであるが，現在の時点では IVP 所見が，最 も簡単で正確であるとして和り ${ }^{26) 27) 28), ~ S h a p i r o ~ は ~ I V P ~}$ 所見がクレアチニンクリアランス值の変動と一致したと のべている゙

長期観察例に和ける IVP 所見の推移については多く

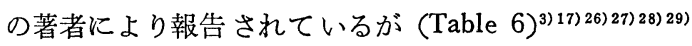
30) 31 32) 33) 34), Gregory らはこれら文献を集積し, 悪化す る率は全体で $9 \%$, 術前正常群で14\%, 術前異常群では $4 \%$ としている ${ }^{28)}$.

Table 6 IVP 所見報告例

\begin{tabular}{|c|c|c|c|c|c|c|c|c|}
\hline \multicolumn{4}{|l|}{ 総 } & \multicolumn{2}{|c|}{ 術前正常 } & \multicolumn{3}{|c|}{ 術前異常 } \\
\hline 報告者 & 改善 & 不変 & 恵化 & 不変 & 悪化 & 改善 & 不変 & 悪化 \\
\hline Malek, R.S. ${ }^{30)}$ & $33 \%$ & $59 \%$ & $8 \%$ & $91 \%$ & $9 \%$ & $51 \%$ & $41 \%$ & $7 \%$ \\
\hline Ray, $P^{311}$ & $29 \%$ & $39 \%$ & $32 \%$ & $68 \%$ & $32 \%$ & $40 \%$ & $28 \%$ & $33 \%$ \\
\hline Smith, E.D. ${ }^{26)}$ & $5 \%$ & $78 \%$ & $16 \%$ & $90 \%$ & $10 \%$ & $14 \%$ & $60 \%$ & $26 \%$ \\
\hline Schmidt, J.P. ${ }^{17)}$ & $46 \%$ & $37 \%$ & $18 \%$ & $72 \%$ & $28 \%$ & $71 \%$ & $17 \%$ & 1296 \\
\hline Delgado, G.E. ${ }^{32)}$ & $38 \%$ & $49 \%$ & $14 \%$ & $70 \%$ & $30 \%$ & $66 \%$ & $33 \%$ & $1 \%$ \\
\hline Wyatt, J.K. ${ }^{33)}$ & $20 \%$ & $64 \%$ & $15 \%$ & $100 \%$ & $0 \%$ & $34 \%$ & $40 \%$ & $26 \%$ \\
\hline Gregory, J.G. ${ }^{28)}$ & $17 \%$ & $72 \%$ & $11 \%$ & $86 \%$ & $14 \%$ & $42 \%$ & $52 \%$ & $6 \%$ \\
\hline Shapiro, S.K. ${ }^{29)}$ & $20 \%$ & $61 \%$ & 1996 & $85 \%$ & $15 \%$ & 4096 & $36 \%$ & $24 \%$ \\
\hline Schwarz, A.W. ${ }^{271}$ & $21 \%$ & $46 \%$ & $33 \%$ & $63 \%$ & $37 \%$ & $33 \%$ & $37 \%$ & $30 \%$ \\
\hline Cass, A.S. ${ }^{34)}$ & $32 \%$ & $55 \%$ & $13 \%$ & $80 \%$ & $20 \%$ & $71 \%$ & $24 \%$ & $5 \%$ \\
\hline 佐川 $^{3)}$ & $14 \%$ & $62 \%$ & $24 \%$ & $72 \%$ & $28 \%$ & $78 \%$ & $15 \%$ & $7 \%$ \\
\hline 自験例 & $9 \%$ & $78 \%$ & $13 \%$ & $90 \%$ & $10 \%$ & $24 \%$ & $57 \%$ & $19 \%$ \\
\hline
\end{tabular}

疾患別の推移では Gregory は，膀脂腫瘍のため行つた 群では，その他の良性疾患に比し，悪化が少なかつたと 報告している ${ }^{28)}$.

われわれの症例も同様の傾向を認め, 良性疾患群にお いて, より高いIVP 所見悪化が認められた.

回腸導管後長期観察例の 腎機能の 推移について Sha- 
piro は術後10年でクレアチニンクリアランスで 40.4〜 $100.2 \mathrm{ml} / \mathrm{min}$ (平均 $64.2 \mathrm{ml} / \mathrm{min}$ ), serum creatinine 0.36 $\sim 1.4 \mathrm{mg} / \mathrm{dl}$ (平均 $0.74 \mathrm{mg} / \mathrm{dl}$ ) に保たれていたと報告 乙29), Malek もまた, $\mathrm{Na}, \mathrm{K}, \mathrm{Cl}, \mathrm{CO}_{2}$, urea について 観察し，良好な結果を得たとしている ${ }^{30)}$.

われわれの症例では, 完全に 4 年間追跡し得たものは 必らずしも多くはないが，大体術前に比し不変に止まつ た。

従来の腸管利用による蓄尿式尿路变向術の合併症とし て，高クロール性酸血症は重要な地位をしめて括り， 導管形式の本術式によりなくなると期待されていた。 事実，本術式により，本合併症は非常に減少したが, Bricker らの報告に引きつづきな牧かなりみられる35). Castro はこの原因として術前腎機能障害，回腸節の運搬 能の低下を挙げている ${ }^{36)}$.

われわれの症例においても2 例認められたが，回腸導 管術後, 通過障害なく腎機能低下が進行する例のあるこ とが知られている。これらの原因として，術前術後の腎 皿腎炎，長すぎる導管，拡張した腎皿一尿管による尿停 滞，および reflux などがあげられている26)27).

われわれの症例に䋇いても，2例とも，術後の尿中細 菌培養が陽性であり, 充分術後も化学療法を行うべき症 例であつたと考えている。

回腸導管による尿路変向後の尿中細菌培養時の採尿法 について, Bishop らは stoma, stoma 直下特よび, 二 重カテーテルにより採尿し，それらを比較し， stoma 周 囲の採尿では尿污染の危険性が高いことを指摘してい る37).われわれもまた同様の所見を認めた ${ }^{38)}$. Spence らは通常の採尿と二重カテーテルによる採尿とを比較し た結果，培養陽性率が半数になつたと報告している ${ }^{39)}$.

感染の頻度については Shapiro ${ }^{29)}$ らは29.5\% Needh$\mathrm{am}^{40)}$ らは71.7\% (以上普通採尿), Spence ${ }^{39)}$ らは16\% としている.

われわれの症例では，培養回数で $25.8 \%$ ，約1/3の症 例に，細菌培養陽性を認めた。またこれらの内，良性疾 患群では，培養回数で50.0\%，症例で $72.7 \%$ ，悪性疾 患群 $14.3 \% ， 19.4 \%$ と比し有意に高かつた。これは良性 疾患群に上部尿路異常例が多いためと考えられる。

また術前, 術後の IVP 所見と比較してみると, IVP 所見不良例に有意に高く認められた。

また McCoy らは腎機能低下のため尿路変向を行つた 群之機能低下以前に行つた群との間の尿培養を比較し, 術前腎機能正常群では96\%が培養陰性であつたとしてい
$ろ^{41)}$.

このことは，術前 IVP 所見異常例に执いては，尿路 変向によつても, 必ずしも感染の危険性を除去し得ず, 術後も厳重に管理する必要を示しているものと考觉られ る.

分離菌種についてみると, Needham は, Klebsiella, Proteus, E. coli の順であつたとし40), Spence は Proteus, E. coli, Pseudomonas の順としている ${ }^{39)}$. われわれ の症例では Proteus mirabilius, Pseudomonas aerginosa, E. coli の順であつた。

回腸導管の予後は悪性疾患は原疾患の悪性度, 良性疾 患は腎機能の程度によるとされている。

自験例はその原疾患の性質より良性疾患, 膀脱腫瘍以 外の悪性疾患, 膀胱腫瘍の 3 群に大別される. 良性疾患 では2 例が腎不全にて慢性血液透析の止むなきに至つた が死亡例は認めなかつた。膀胱腫瘍以外の悪性疾患では 子宮癌症例が 1 例, 癌再発にて死亡しているが, これら

Table 7 膀胱腫湟生存率

\begin{tabular}{|c|c|c|c|c|}
\hline & & \multicolumn{3}{|c|}{5 年生存淬 } \\
\hline 報 告 者 & 術 式 & 部 & $\mathrm{B}_{1}$ 以下 & $\mathrm{B}_{2}$ 以上 \\
\hline Brice, M.II \& Whitmore, W.F. ${ }^{42)}$ & Simple & $21 \%$ & $37 \%$ & $9 \mathscr{6}$ \\
\hline Whitmore, W.F. ${ }^{43)}$ & Radical & 2196 & $47 \%$ & 996 \\
\hline Jewett, H.J.44 & Simple & $21 \%$ & $50 \%$ & $9 \%$ \\
\hline Cordonnier, J. J. ${ }^{45)}$ & Simple & $38 \%$ & $53 \%$ & $17 \%$ \\
\hline Boles, W. T. ${ }^{47)}$ & Simple & $38 \%$ & $61 \%$ & $14 \%$ \\
\hline [田崎 ${ }^{21}$ & Radical/Simple & $50 \%$ & $74 \%$ & $25 \%$ \\
\hline 自験例 & Radical/Simple & $58 \%$ & $88 \%$ & $36 \%$ \\
\hline
\end{tabular}

疾患は膀胖癌と悪性度が異なり，尿路変向に至つた理由 が手術合併症に対してであるので膀脱癌群と区別した。

膀胼腫瘍37例の実測生存率は58\%であつた。内外の文 献をみてみると Whitmore (単純全摘) ${ }^{42)}, 21 \%$ ，(根治 全摘） ${ }^{43)}, 21 \%$, Jewett ${ }^{44)}, 21 \%$, Cordonnier ${ }^{45)}, 38 \%$, $\mathrm{Richie}^{46)}$, 44\%，田崎 ${ }^{2)}$ ，50\%，佐川 ${ }^{3)} ， 60 \%$ とされてい る (Table 7).

根治全摘が単純全摘かについては議論のわかれるとこ ろであるが, 自験例では 5 年生存が $46 \%$ か $82 \%$ へと改 善が認められ，また特に $\mathrm{P}_{3}$ 以上の high stage 群で 5 年 生存 $26 \%$ から67\% と改善がめざましかつた。

\section{まとめ}

1） 1963年より1976年の間に経験した57症例の回腸導 管の原疾患は膀胱腫瘍37, 膀胱腫瘍以外の骨盤内悪性腫 瘍 9 ，良性疾患11であつた。これら症例の手術成績，合 併症，腎機能尿路感染などについて検討を加えた。 
2）回腸導管術後の合併症としては創部感染が最も多 く, 次いで腸閉塞, 上部尿路結石, 尿瘦の順であつた。 また良性疾患群では晚期合併症, 墨性疾患群にては早期 合併症が多い傾向が見られた。

3）IVP 所見の推移では，術後悪化率は悪性疾患の $9.1 \%$ に比し良性疾患は $30.0 \%$ と有意に高かつた。血液 生化学の所見は, 長期観察例に招いても大きな変動は認 められなかつた。

4）二重カテーテルを用いた，尿中細菌の検索では， 悪性疾患群では陽性例が19\%であるのに比し良性疾患群 では陽性例73\%と有意に高かつた。また培責陽性と上部 尿路の変化とは強い関連を示した。このことは，上部尿 路異常例に打いては術後も充分尿路感染症に注意する必 要性を示していると考兄られる。

5）膀胱腫㵣37例の実測 5 年生存率は $58 \%$ で，根治的 膀胼全摘群のそれは $82 \%$ であり, 単純全摘群の $46 \%$ に比 し良かつた. 特に $\mathrm{P}_{3}$ 以上の high stage 群に打いて単純 全摘26\%に比し根治全摘67\%と良好な結果であつた。

(本論文の一部要旨は第64回日本泌尿器科学会総会に て発表した。本論文の統計学的処理に際ししては塩野義 解析センターの御協力を得たことを記し感謝します。ま た直接指導いただいた九州厚生年金病院泌尿器科尾本徹 男博士に感謝するととも協力していただいた教室員一同 に感謝します。終りに御指導御校閲いただたた百瀬俊郎 教授に感謝します。)

\section{文献}

1) Bricker, E.M.: Bladder substitution after pelvic evisceration. S. North Amer., 30, 1511$1521,1950$.

2）田崎 寛: 回腸導管の遠隔成績。日泌尿会誌, 66, 493-509, 1975.

3）佐川史郎, 有馬正明, 秋山隆弘, 長船匡男, 八 竹 直, 高羽 津, 古武敏彦, 水谷修太郎：骨 盤腔内悪性腫湟患者に対する尿路变向法. 日泌 尿会誌，66，785-792，1975.

4) Koss, L.G.: Tumors of the urinary bladder, Armed forces institute of pathology, Washington, 1973.

5) 栗原 登, 高野 昭: 癌の治瘉率の計算方法に ついて。癌の臨床, 11，628-633，1965.

6) Parkhurst, E.C. and Leadbetter, W.F.: A report on 93 ileal loop urinary diversion. J. Urol., 83, 398-403, 1960.

7) Clark, S.S.: Electrolyte disturbance associated with jejunal conduit. J. Urol., 112, 42-47, 1974.
8) Mogg, R.A.: The treatment of neurogenic urinary incontinence using the colonic conduit. Brit. J. Urol., 37, 681-686, 1965.

9) Richie, J.P. and Skinner, D.G.: Urinary diversion; The physiological rationale for non refluxing colonic conduit. Brit. J. Urol., 47, 269-275, 1975.

10) Morales, P. and Golimbu, M.: Colonic urinary diversion; 10 years of experience. J. Urol., 113, 302-307, 1975.

11）神崎仁德, 岩坪暎二, 尾本徹男: 脊損膀腅に打 ける回腸導管。西日泌尿, 38, 77-84, 1976.

12) Creevy, C.D.: Renal complication after ileac diversion of the urine in non neoplastic disorders. J. Urol., 83, 394-397, 1960.

13) Kaufman, J.J.: The ureter. Hoeber, New York, 1967.

14) Smith, R.B., Cangh, P.V., Skinner, D.G., Kaufman,J.J. and Goodwin, W.E.: Augumentation enterocystoplasty. J. Urol., 118, 35-39, 1977.

15) Cordonnier, J.J. and Nicolai, C.H.: An evaluation of the use of an isolated segment of ileum as a mean of urinary diversion. J. Urol., 83, 834-838, 1960.

16) Engel, R.M.: Complications of bilateral uretero-ileo cutaneous urinary diversion. J. Urol., 101, 508-512, 1969.

17) Schmidt, J.P., Hawtrey, C.E., Flocks, R.H. and Culp, D.A.: Complications, results, and problems of ileal conduit diversion. J. Urol., 109, 210—216, 1973.

18) Price, S.E. Jr.: Ileal conduit urinary diversion in children. J. Urol., 114, 444-448, 1975.

19) Manley, C.B., Silber, I. and Cordonnier, J.J.: Intestinal obstructions following ileal segment diversion. J. Urol., 101, 840-845, 1969.

20) Hensle, J.W., Bredin, H.C. and Dretler, S.P.: Diagnosis and treatment of urinary leak after uretero-ileal conduit for diversion. J. Urol., 116, 29-31, 1976.

21) Hofman, A.F.: Bile acid malabsorption caused by ileal resection. Arch. Intern. Med., 130, 597-605, 1972.

22) Schmidt, J.P. and Hodgson, N.B.: Bile salt diarrhea. J. Urol., 112, 536-537, 1974.

23) Rogers, A.C.N. and Styn, Г.H.: Vitamin $B_{12}$ absorption in patients with ileal resection. Brit. J. Urol., 46, 625-629, 1974.

24) Schmidt, J.P., Hawtrey, C.E. and Buchsbaum, H.J.: Transverse colon conduit. J. Urol., 113, 308-313, 1975.

25) Dretler, S.P.: The pathogenesis of urinary 
tract caliculi occuring after ileal conduit diversion. J. Urol., 109, 204-209, 1973.

26) Smith, E.D.: Follow up studies on 150 ileal conduits in children. J. Pediat. Surg., 7, 110, 1972.

27) Shwarz, G.R. and Jeffs, R.D.: Ileal conduit urinary diversion in children; Computer analysis of follow up from 2 to 16 years. J. Urol., 114, 285-288, 1975.

28) Gregory, J.P., Gursahani, M. and Schoenberg, H.W.: Five year radiographic review of ileal conduit. J. Urol., 112, 327-331, 1974.

29) Shapiro, S.R., Lebowitz, R. and Colodny, A.H.: Fate of 90 children with ileal conduit urinary diversion, decade later. J. Urol., 114, 289-295, 1975.

30) Malek, R.S.Burke, E.C. and Deweerd, J.H.: Ileal conduit urinary diversion in children. J. Urol., 105, 892—895, 1971.

31) Ray, P. and Pomenico, I.D.: Intestinal urinary diversion in children. Brit. J. Urol., 44, 345-350, 1972.

32) Delgado, G.E. and Muecke, E.C.: Evaluation of 80 cases of ileal conduit in children. J. Urol., 109, 311-315, 1973.

33) Wyatt, J.K.: Ileal conduit diversion for benign disease. Canad. J. Surg., 17, 270274, 1974.

34) Cass, A.S.: Urinary diversion for neurogenic bladder in children. J. Urol., 115, 314-316, 1976.

35) Bricker, E.M.: Functional results of small intestinal segments as bladder substitutes following pelvic evisceration. Surgery, 32, 372-383, 1952.

36) Castro, J.E.: Electrolyte imbalance following ileal urinary diversion. Brit. J. Urol., 42, 29-
32, 1970.

37) Bishop, R.F., Smith, E.D. and Gracey, M.: Bacterial flora of urine from ileal conduit. J. Urol., 105, 452-455, 1971.

38）神崎仁德，熊沢浄一：回腸導管に打子る尿路感 染症一特に採尿法について一。西日泌尿に投稿 中.

39) Spence, B., Stewart, W. and Cass, A.S.: Use of double lumen catheter to determine bacteriuria in intestinal loop diversion in children. J. Urol., 108, 800-801, 1972.

40) Needham, R.N., Smith, M.M. and Matsen, J.M.: Differences in bacteriology of intestinal loop urinary diversion. J. Urol., 104, 831-833, 1970.

41) McCoy, R.M. and Rhamy, R.K.: Ileal conduit in children. J. Urol., 103, 491-495, 1970.

42) Brice, M. Jr., Marshall, V.F., Green, J.L. and Whitmore, W.F. Jr.: Simple total cystectomy for carcinoma of the urinary bladder. Cancer, 9, 576-584, 1956.

43) Whitmore, W.F. Jr. and Marshall, V.F.: Radical total cystectomy for cancer of the bladder. J. Urol., 87, 853-868, 1962.

44) Jewett, H.J., King, L.R. and Shelley, W.M.: A study of 365 cases of infiltrating bladder cancer. J. Urol., 92, 668-678, 1964.

45) Cordonnier, J.J.: Cystectomy for cancer of the bladder. J. Urol., 99, 172-173, 1968.

46) Richie, J.P., Skinner, D.G. and Kaufman, J.J.: Radical cystectomy for carcinoma of the bladder. J. Urol., 113, 186-189, 1975.

47) Bowles, W.T. and Silber, I.: Carcinoma of the bladder. J. Urol., 107, 245-247, 1972.

(1978年12月26日受付，特別掲載） 